\title{
Prospects for Improving Irrigated Agriculture in Southern Africa: Linking Water, Energy and Food
}

\author{
Tafadzwanashe Mabhaudhi ${ }^{1, *}(\mathbb{D})$, Sylvester Mpandeli ${ }^{2}$, Luxon Nhamo ${ }^{3}(\mathbb{D}$, \\ Vimbayi G. P. Chimonyo ${ }^{1}\left(\mathbb{D}\right.$, Charles Nhemachena ${ }^{3}{ }^{(\mathbb{D}}$, Aidan Senzanje ${ }^{4}$, Dhesigen Naidoo ${ }^{2}$ and
} Albert T Modi ${ }^{1}$

1 Centre for Transformative Agricultural and Food Systems, School of Agricultural, Earth and Environmental Sciences, University of KwaZulu-Natal, P/Bag X01, Scottsville, Pietermaritzburg 3209, South Africa; chimonyov@ukzn.ac.za (V.G.P.C.); modiat@ukzn.ac.za (A.T.M.)

2 Water Research Commission, 4 Daventry Street, Lynnwood Manor, Pretoria 0081, South Africa; sylvesterm@wrc.org.za (S.M.); dhesn@wrc.org.za (D.N.)

3 International Water Management Institute (IWMI-SA), 141 Cresswell St, Weavind Park, Silverton, Pretoria 0184, South Africa; l.nhamo@cgiar.org (L.N.); C.Nhemachena@cgiar.org (C.N.)

4 School of Engineering, University of KwaZulu-Natal, P/Bag X01, Scottsville, Pietermaritzburg 3209, South Africa; senzanjea@ukzn.ac.za

* Correspondence: mabhaudhi@ukzn.ac.za; Tel.: +27-33-260-5442

Received: 14 November 2018; Accepted: 12 December 2018; Published: 19 December 2018

\begin{abstract}
Increasing agricultural productivity has always been a prominent feature on the regional agenda due to a high incidence of food and nutrition insecurity. This review assessed the current status of irrigated agriculture in southern Africa from a water-energy-food (WEF) nexus perspective. Gaps and opportunities for improving irrigated agriculture within the context of the WEF nexus were also assessed in terms of the feasible limits to which they can be exploited. Southern Africa faces water scarcity, and climate projections show that member states will face increased physical and/or economic water scarcity by as early as 2025, which will have negative impacts on water, energy and food production. Recurrent droughts experienced across the region reaffirm the sensitive issues of food and energy insecurity as well as water scarcity. Projections of an increasing population within the region indicate increased water, energy and food demand. With agriculture already accounting for about $70 \%$ of water withdrawals, increasing the area under irrigation will place additional demand on already strained energy grids and scarce water resources. This poses the question-is increasing irrigated agriculture a solution to improving water access, food security and energy supply? While there are prospects for increasing the area under irrigation and subsequent improvement in agricultural productivity, adopting a WEF nexus approach in doing so would mitigate trade-offs and unintended consequences. Consideration of the WEF nexus in integrated resources planning and management eliminates the possibilities of transferring problems from one sector to other, as it manages synergies and trade-offs. While it is acknowledged that improving water productivity in irrigated agriculture could reduce water and energy use while increasing yield output, there is a need to decide how such savings would then be reallocated. Any intervention to increase the irrigated area should be done in the context of a WEF nexus analytical framework to guide policy and decision-making. Technical planning should evolve around the WEF nexus approach in setting targets, as WEF nexus indicators would reveal the performance and impact of proposed interventions on any of the three WEF nexus components.
\end{abstract}

Keywords: irrigation; southern Africa; WEF nexus; water productivity; water accounting; agriculture 


\section{Introduction}

The current challenges facing agriculture are compounded by multiple stressors, which include, but are not limited to, increases in food demand, growing populations, migration, urbanisation and climate variability and change [1]. In addition to this classical Malthusian challenge, the growth of the middle class and accompanying resource demands presents an interesting conundrum from a resource management perspective. Africa's developmental ambitions, as laid out in Vision 2063 and other continental frameworks, make it clear that we are envisaging higher levels of development that will, among other things, see increased industrialisation on the continent [2,3]. If the continent proceeds with the current industrialisation paradigm, the resource strain will increase. As it is, $43 \%$ of southern Africa is either arid or semiarid, while about $70 \%$ of the people rely on rainfed agriculture and face food insecurity [1,2]. Recurring droughts and other extreme weather events threaten the sustainability of agriculture. While irrigation has the potential to boost agricultural productivity by 50\% [3], it currently accounts for 9\% of the southern Africa's arable land, and the figure decreases to 7\% for all of Africa [4]. This is far below developing regions such as South America (41\%) and Southeast Asia (29\%) [5], with which we share similar development trajectories. This has led to the argument that improvements in crop productivity lie in increasing the area under irrigated agriculture [6]. However, given the interlinkages between water, energy and food, there is need to adopt an integrated water-energy-food (WEF) nexus approach that balances the needs across sectors and mitigates trade-offs [7].

The WEF nexus addresses the complex and interrelated nature of resource systems [8]. It presents a holistic approach to better understand and systematically analyse the interactions between the natural environment and human activities, and to work towards a more coordinated management and use of natural resources across sectors and scales. The WEF nexus approach potentially provides a way of understanding the complex and dynamic interlinkages between food security, irrigation and water resources, which together constitute a theme around sustainable food production [4]. For example, the United Nations has recognised the WEF nexus as an important approach to achieving the Sustainable Development Goals (SDGs) on poverty alleviation, zero hunger, the provision of clean water and sanitation and access to affordable and reliable energy (Goals 1, 2, 6 and 7, respectively) [9].

This review assesses the prospects of increasing the area under irrigation in southern Africa in the context of the WEF nexus. This was achieved by (i) assessing the current status of agriculture, water and energy in the region; (ii) assessing the prospects for increasing the area under irrigation; and (iii) providing a WEF nexus perspective for achieving and balancing regional food security goals.

The focus is on southern Africa (Figure 1), which forms part of the Southern African Development Community (SADC). For the purpose of this study, we have focused on the mainland states in the analyses; this is because most of the shared and transboundary resources, as well as data availability, are within the context of the mainland states. The first section of the review outlines Africa's and southern Africa's visions for achieving food and nutrition security and the role of irrigated agriculture. The second section then assesses the status of water, energy and food in southern Africa and gives an overview of the irrigation potential within the region. The main objective of this section was to set the scene for the adoption of the WEF nexus relative to regional goals and ambitions. The section highlights possible trade-offs and synergies within the WEF nexus. The third and last section lists recommendations for the integration of the WEF nexus when considering irrigation expansion for improved agricultural productivity. 


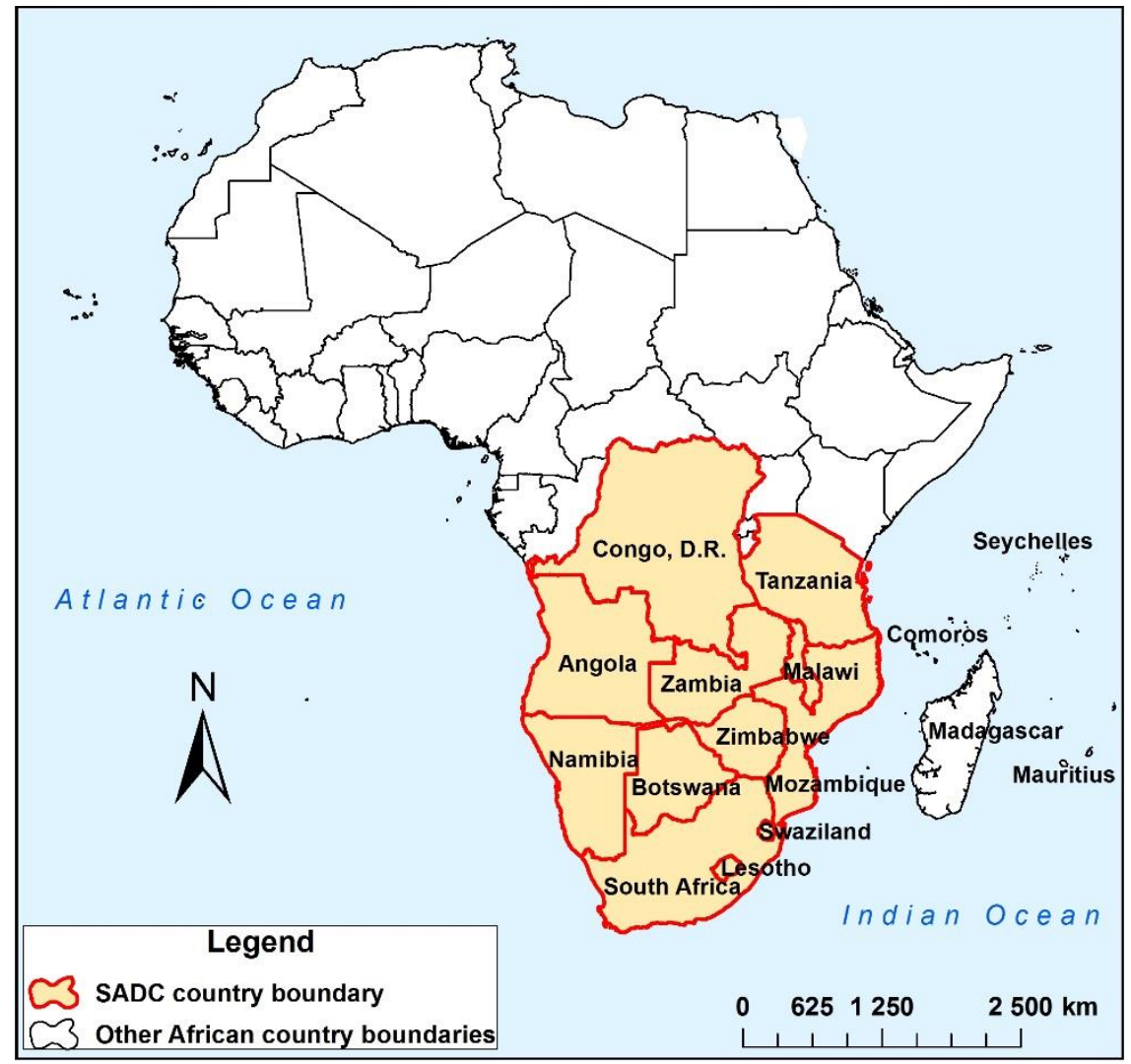

Figure 1. Location of Southern African Development Community (SADC) countries in Africa. Source: Developed by the authors. Note: Madagascar, Mauritius, Seychelles and Comoros are part of the SADC, but are not highlighted in colour as the study is focussing on mainland southern Africa.

What Is the Vision for Food Security in Africa and Southern Africa?

Nearly 240 million people in sub-Saharan Africa (SSA), or one person in every four, lack adequate food for a healthy and active life, and record food prices and drought are pushing more people into poverty and hunger [10]. By 2050, Africa's population will have more than doubled to 2.4 billion people. In addition, two-thirds of Africa is arid or semiarid, and 38\% of people in SSA live in water-scarce environments [5]. Smallholder farms represent $80 \%$ of all farms in SSA and contribute up to $90 \%$ of the agricultural production in some SSA countries [11]. However, they too suffer from food insecurity as they rely on rainfed agriculture, meaning that if there is drought, there are food shortages. Improving agriculture on small farms is critical for reducing hunger. In response to the widening food crises in Africa, with a specific mandate to promote agricultural investment and development to combat hunger and poverty, the Comprehensive Africa Agriculture Development Programme (CAADP) spearheaded by the New Partnership for Africa's Development (NEPAD) in partnership with the United Nations' Food and Agriculture Organisation (FAO) $[12,13]$ was launched. The CAADP set four pillars: (i) extending the area under sustainable land management and reliable water control systems, (ii) improving rural infrastructure and trade-related capacities for improved market access, (iii) increasing food supply and reducing hunger, and (iv) increasing research and development. Targeted investments in these pillars would bring immediate transformations to Africa's food security crises. It suggested that rapidly increasing the area equipped with irrigation, especially small-scale irrigation, could provide opportunities for farmers to sustainably increase yield and address food insecurity. The CAADP proposed increasing the area under irrigation (new and rehabilitated) to 20 million ha, at an estimated cost of US\$37 billion, while infrastructure operation and maintenance required a further US\$31 billion. 
The CAADP addressed this by placing emphasis on prioritising investment in small-scale irrigation, setting a target of about 14.2 million ha for small-scale irrigation schemes. The 2014 Malabo Declaration signed by African Heads of State and Government in Equatorial Guinea recommitted to the principles of the CAADP, including additional commitments for the continent to end hunger by 2025 [14]. Interventions required to achieve the continental goal and targets of ending hunger included doubling crop productivity by focussing on inputs, irrigation and mechanisation [14]. The SADC's Regional Indicative Strategic Development Plan (RISDP) [15] and Regional Agricultural Policy (RAP) [16], informed by the CAADP, also highlighted the need to improve crop productivity through increasing irrigation. Although the CAADP seeks to promote irrigation, among other interventions, it also noted that increased irrigation was not the panacea for all of Africa's food security ills. There is a need to complement such interventions with improvements in water productivity, nutrition and human health $[17,18]$. A holistic and systems approach would be best placed to sustainably tackle the complex challenge of food insecurity.

Increasing the irrigated area implies increasing water withdrawals for agriculture, which already accounts for the bulk of freshwater withdrawals. Secondly, it requires significant investments in infrastructure and energy, especially in countries with economic water scarcity. Thirdly, irrigation requires significant energy outlays to pump and distribute water, yet the region currently faces energy insecurity; but at the same time, needs to produce more food to feed a growing population [19]. The SADC's RAP also prioritises energy availability for irrigation, adding an interesting section that stresses the significance of the region's shared water resources and the establishment of cross-border irrigation schemes. The importance of incorporating energy in development planning [20] and the transboundary nature of the SADC's watercourses [7] underlines the need to balance and coordinate resource development through the WEF nexus. Figure 2 presents a map of southern Africa showing the current distribution of agricultural area by system. Irrigated area accounts for only $9 \%$ of southern Africa's arable land.

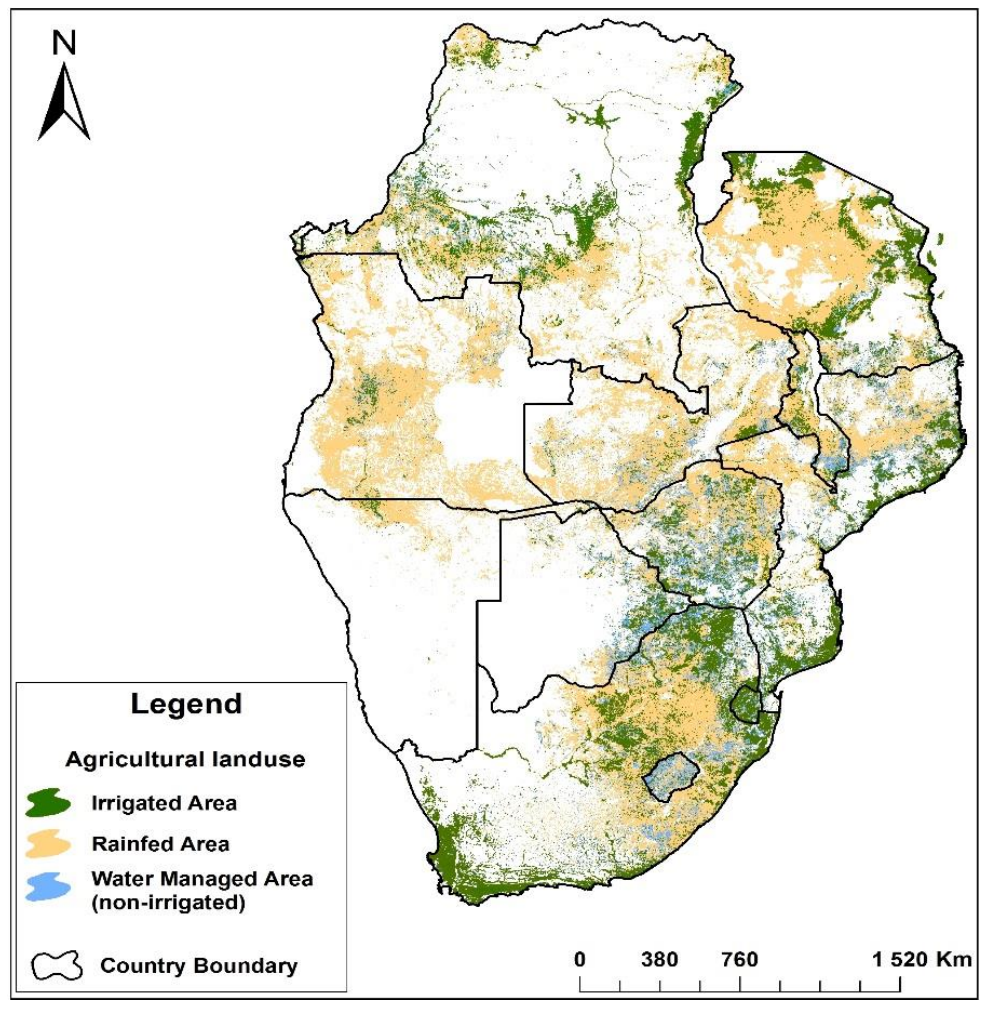

Figure 2. Cultivated land use by agricultural system in southern Africa. Source: International Water Management Institute's (IWMI) Irrigated Area Map [21]. 


\section{WEF Nexus Considerations for Expanding the Area under Irrigation}

\subsection{Water for Agriculture: Irrigation Infrastructure Development in Southern Africa}

It is envisaged that southern Africa will become drier in the near future, negatively impacting vulnerable and poor smallholder farmers with low adaptive capacity. Most of the arable land in southern Africa is under smallholder farmer use [11]. Heavy reliance on rainfall for agriculture makes them vulnerable to the negative impacts of climate variability and change. Due to the increasing uncertainty in water availability, the viability and sustainability of rainfed cropping systems will gradually decline [22]. On the other hand, increasing populations, changing dietary requirements and increasing middle-class earnings will lead to the requirement of more food under the same limited water conditions. If the region is to increase the area under irrigation for increased agricultural production, the damming of runoff water is vital.

Of the total mean annual runoff (MAR) of $98,926 \mathrm{~km}^{3} /$ year in southern Africa, only $0.43 \%$ is dammed and the remaining $99.57 \%$ is underutilised; most of the surface water flows to the ocean [23]. Thus, there is a need to build more dams to store the water which just flows to the ocean without being used for irrigation and other purposes. Projections indicate that $14 \%$ more water will be needed for irrigated agriculture in developing countries alone by 2030 [24]. This requires some $220 \mathrm{~km}^{3}$ of extra storage. Current storage capacity is dwindling through the siltation of existing reservoirs. Storage losses through siltation are estimated at about $1 \%$ or $60 \mathrm{~km}^{3} /$ year. This implies that more reservoirs should be constructed to meet the additional water requirements needed to meet the CAADP target of 5 million ha of irrigated land by 2025, whilst at the same time rehabilitating and maintaining current water infrastructure. Dam construction may exclude countries such as Zimbabwe and South Africa, which already have a high density of dams (Figure 3), but may need rehabilitation.

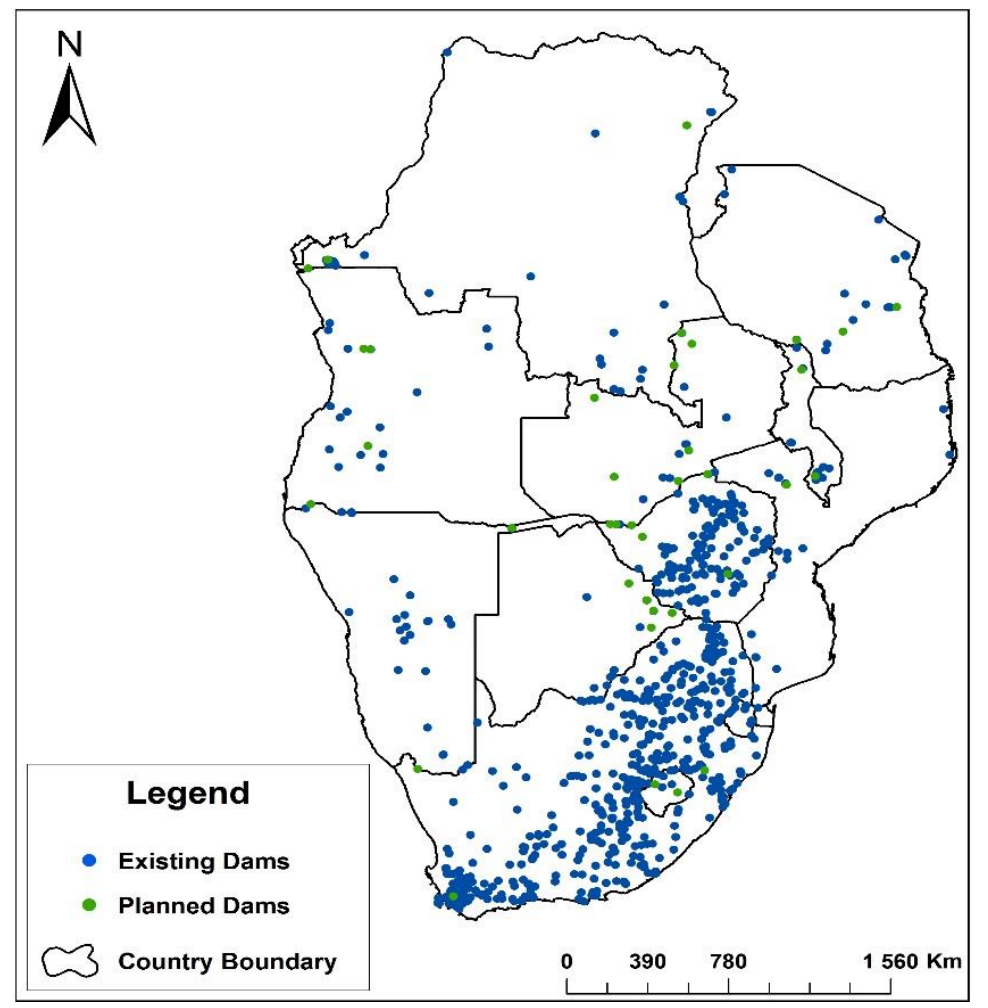

Figure 3. Existing and proposed dams in southern Africa. Source: Developed by authors from FAO Aquastat data [25]. 
Damming creates plausible opportunities for promoting programmes for irrigation expansion. With the exception of South Africa and Zimbabwe, the rest of the SADC countries have very few dams that can ensure surface water availability throughout the year. The two countries also have much of their arable land equipped for irrigation (see Table 1 and Figure 3). The distribution of the 819 dams in the region is uneven (see Figure 3), making the implementation of policy on irrigation difficult. Even though there are 38 planned dams in the north (see Figure 3), they may not be enough to meet the water requirements, let alone the energy requirements, needed to irrigate the proposed 5 million ha by 2025. However, with countries such as South Africa which are already at the limit of feasible dam construction, this highlights that a regional water investment/transfer strategy would be needed. Besides increasing dams within the region, irrigation projects should be based on proper planning (assessment of catchment-based water potential), improved water-use efficiency and agricultural water management.

Table 1. Area of irrigation potential and area under water management in southern African countries.

\begin{tabular}{ccccc}
\hline Country & $\begin{array}{c}\text { Irrigation Potential } \\
\mathbf{( 1 0 0 0} \mathbf{h a )}\end{array}$ & $\begin{array}{c}\text { Irrigation Potential } \\
\text { Equipped for } \\
\text { Irrigation (1000 ha) }\end{array}$ & $\begin{array}{c}\text { Potential Area for } \\
\text { New Irrigation } \\
\text { Development (1000 ha) }\end{array}$ & $\begin{array}{c}\text { Area Under Non-Equipped } \\
\text { Agricultural Water } \\
\text { Management (1000 ha) }\end{array}$ \\
\hline Angola & 3700 & 85.5 & 3614.50 & 0.4 \\
Botswana & 13 & 1.4 & 11.6 & 6.5 \\
DRC* & 7000 & 10.5 & 6989.50 & 3 \\
Lesotho & 13 & 2.6 & 9.9 & 0 \\
Malawi & 162 & 73.5 & 88.4 & 0 \\
Mozambique & 3072 & 104.4 & 2967.60 & 13.7 \\
Namibia & 47 & 7.6 & 39.7 & 2 \\
South Africa & 1500 & 1500.00 & 0 & 170 \\
Swaziland & 93 & 49.9 & 43.4 & 4935.10 \\
Tanzania & 2132 & 184.2 & 1947.80 & 0.3 \\
Zambia & 523 & 155.9 & 367.1 & 100 \\
Zimbabwe & 366 & 173.5 & 192.1 & 20 \\
SADC & 18,621 & 5626.2 & $12,994.4$ & 5250.9 \\
\hline
\end{tabular}

Source: FAO Aquastat database [25]. *DRC = Democratic Republic of Congo.

The present scenario, where agriculture accounts for the bulk of freshwater withdrawals, while food insecurity is unsustainable, requires that we focus on improving water productivity in agriculture. This will address both the issue of reducing water use in agriculture and increasing agricultural productivity. Improving water productivity would suggest minimising, where possible, unproductive water losses [26], such as soil evaporation, drainage and runoff. This would also entail improving agricultural water management to reduce water use and avail it for other sectors. At a field level, improvements in water productivity could be realised through a combination of improved agronomic, engineering, management and institutional strategies. Rainwater harvesting and soil water conservation should be promoted, especially for smallholder farmers. The use of improved varieties with high water productivity and improved agronomic practices that contribute to increased water productivity should be strengthened. Alternative practices such as intercropping could be considered for smallholder farmers, as they allow for increased water productivity [27,28]. Investments in irrigation should favour efficient systems, such as micro-irrigation systems (drip and subsurface irrigation) in the place of macro-irrigation systems (overhead and sprinkler-type irrigation). Micro-irrigation has the potential to achieve the highest uniformity $(90 \%)$ in the water applied to each plant relative to macro-irrigation [29]. Management strategies such as deficit irrigation should be adopted, as they can increase water productivity. Improving water productivity would translate to lower energy and water use, hence relieving pressure on the WEF nexus. However, this will require developing institutional arrangements to support coordinated agricultural water management in catchments and at the field scale. 


\subsection{Water for Energy}

Water and energy are critical resource inputs for economic growth and food security [30], as well as for irrigation. Southern Africa has vast but unexploited water and energy resources. However, the majority of the population in the region already lacks access to clean and reliable water and energy [31]. Irrigation expansion at a time when the region is still depending on hydropower as the main source of energy may exacerbate the challenges of water and energy supply in the region. With the exception of South Africa, less than $30 \%$ of southern Africa's population has access to electricity and uses biomass fuel for cooking and heating [32]. To improve access to energy for all, the region has the potential to increase energy supply through hydroelectric, fossil and biofuels; however, this means more water supply is required [33]. Then again, to improve water supply to urban areas for irrigation and to food-processing industries, more energy is required to pump and distribute the water [34]. Water for energy and energy for water are two challenges that have emerged in the last century that can potentially affect the need to expand the area under irrigation. The WEF nexus analytical approach looks into all these scenarios to guide policy harmonisation and thereafter coordinate implementation. The alternative in such a scenario would be to turn to the vast solar and wind energy potential in the region, sources of energy that do not require a lot of water.

In most energy-production processes, water is an essential input: fossil fuels require water for extraction, transport and processing; it is used for cooling in thermoelectric generation based on nuclear and fossil fuels; and hydropower can be produced only if water is readily available in rivers or reservoirs $[10,34,35]$. Feedstock production for biofuels, such as ethanol, may depend on water for irrigation, and renewable energy resources such as solar require water for cooling and cleaning panels or collectors for improved efficiency [10]. Solar photovoltaic (PV) and wind technologies demand minimal quantities of water $[20,36]$. Energy is itself required to make water resources available for human use and consumption (including irrigation) through pumping, transportation, treatment and desalination [10]. The technology choice, source of water and fuel type determine the impacts of energy on the withdrawal, consumption and quality of water resources. These factors are taken into consideration when assessing a country's performance in resources management and ranking its sustainability level through the WEF nexus analytical approach. The same factors are also looked into when assessing performance of a country towards achieving SDG targets.

\subsection{Energy for Agriculture}

The correlation between food security and energy demand has been widely established [37]. Agriculture and the food sector use about $30 \%$ of the global energy [38], and this is expected to increase owing to the increase in the demand for food. With the exception of South Africa, southern Africa is energy-poor, with more than $60 \%$ of its population having no access to electricity and using biomass energy sources for heating, cooking and lighting [39]. The region faces severe energy poverty, and the low availability of energy services hampers economic development, and more importantly, threatens the expansion of land under irrigation. Data on the amount of energy used for irrigation on a regional scale is largely unavailable, making it difficult to quantify the extent to which it will influence the WEF nexus if we are to increase the area under irrigation. Energy used in irrigation can account for $>50 \%$ of a farm's total energy bill [40,41]. Increasing irrigated area may see farmers paying an additional $70 \%$ for energy on their total farm bills. However, the increasing scarcity of fossil energy sources, urbanisation, dilapidating energy infrastructure and a lack thereof, and correspondingly, rising energy prices are further challenges concerning the access of energy for increased agricultural productivity [42]. Expanding the area under irrigation creates new energy demands on already strained energy grids [38]. As it is, evidence suggests that the current energy status of the region cannot accommodate the present or future expansion of the area under irrigation. Low tariffs, poor project preparation, issues with power purchase agreements and absent regulatory frameworks stunt investment and financing in the energy sector. In response to the need to increase energy access in agriculture for increased productivity, the development and use of renewable energy sources such as solar photovoltaic (PV) and 
wind technologies [20,36] has increased over the last decade [10,43,44]. Several countries (Zimbabwe, Mozambique, Zambia and Tanzania) have invested in the construction of dual-purpose dams that generate hydroelectricity and water for irrigation [16,45]. This would provide enough energy for irrigation and provide additional energy released to the energy grid for other uses. In addition to this, bioenergy has become a potential source by which to increase energy within the region.

By 2050, model scenarios project bioenergy growth to reach 35\% of the global primary energy, and by 2100 , bioenergy will contribute 10 to $50 \%$ of the global primary energy $[46,47]$. This suggests that bioenergy will contribute directly to energy for irrigation in the near and distant future. The argument for bioenergy is centred on the net emission of carbon dioxide, which is said to be negligible as long as plants continue to assimilate for biomass energy purposes [48], hence contributing to the mitigation of carbon emissions. However, the net emissions associated with biomass use for energy services can easily be negated because of the complexity of challenges emanating from potential changes in land use and land management, and its apparent demand on resources-energy, water and nitrogen [49]. Land use issues that often arise are the assumed conflicts between food production and biomass crops. Within the context of the WEF nexus, there is competition for land between food production and biofuels feedstock production; hence the need for the WEF nexus as a planning tool [19]. It is counter-argued that the large-scale cultivation of biomass strengthens the agenda around bioenergy and inevitably increases global food prices and increase in water withdrawals through irrigation [50]. According to Kline et al. [47], long-term data shows little to no correlation between food price, increases in water use and bioenergy. Kline et al. [47] go on to argue that when risks are observed, bioenergy can actually address food security concerns, since in most instances, they are food crops. Popp et al. [50] suggest the use of integrated landscapes where agricultural, forestry and biofuel crops can be produced simultaneously to increase the sustainability of bioenergy. Producing biomass on underutilized land under rainfed conditions could also reduce competition with food crops for irrigation water [47]. At a smaller scale, systems that include crop rotations, multiple cropping, intercropping across seasons and agroforestry approaches can reduce the risk.

On the other hand, because of the close association between bioenergy and food, the use of biomass has the potential to create environmental and social challenges beyond its use as a substitute for fossil fuels [19,51]. Impacts on soils, water resources, biodiversity, ecosystem function and local communities will differ depending on choices made regarding the types of biomass used, as well as where and how they are produced $[47,52,53]$. The extent of these impacts also depends on uncertainties which are biophysical (e.g., carbon density, land productivity, and climate) and economic (e.g., land conversion and yield responses) [54]. As it is, the water footprint for biomass production for bioenergy is said to be higher than that of fossil fuels, as water is required along the entire value chain [55]. Under rainfed conditions, a profitable biofuel enterprise will require irrigation to maximise productivity. In view of these uncertainties and risks associated with their production, proponents for bioenergy are calling for more efficient value chains and alternative crop choices that do not threaten the status quo of food production. Next- or second-generation biofuels, also known as advanced biofuels, can be used to promote increase investments in bioenergy. Second-generation biofuels are manufactured from various types of non-food biomass and/or food waste and are produced using new technology [44]. Some of these technologies are also aimed at converting cellulosic fractions from crops into biofuels [56]. This fraction of biofuels can substantially increase the production sustainability of the industry. Second-generation biofuels are said to have a small impact on the WEF nexus when compared with first-generation biofuels, as they do not directly compete for land, water, food or energy. Within the context of the WEF nexus, the use of second-generation biofuels can support the interrelationships among first-generation biofuels and the different sectors within the nexus by relieving competition for resources. The use of both first- and second-generation biofuels can help offset the demands of food and water and provide a greater contribution towards energy supply. However, the production and trade of second-generation biofuels in southern Africa is limited [56]. The difficulties of African biofuels production are attributed to unsustainable large-scale projects, several of them involving 
Jatropha, and controversies over land-grabbing allegations [56,57]. Given all these investments and the need to provide more energy across multiple sectors, policy-makers should consider a WEF nexus approach when planning the development of biofuels to balance competing demands.

\subsection{Water Markets and the WEF Nexus}

The ability of early civilizations, and more recently, nations to move water to and within fields has depended on the availability of energy [58-60]. This transfer of water from one sector to another is referred to as water marketing and is predominant in areas experiencing water scarcity [8]. Water marketing involves the transfer or sale of water or water rights among users and is often done without investing in new infrastructure [61]. A good example of water marketing is the inter-basin water transfers in a region, where water is transferred from one basin to the other (Figure 4 ). One such inter-basin water transfer agreement is the Lesotho Highlands Water Treaty [6,7], which culminated with the formation of the Lesotho Highlands Water Project, which has clearly defined volumetric allocation based on known flows. The Lesotho Highlands Water Project addresses South Africa's water scarcity challenges through the transfer of some of Lesotho's abundant water resources to the Gauteng region. The revenues from the project are enabling Lesotho to develop its hydropower capacity and improve water distribution within the country [8]. This is a good case of a balanced WEF nexus initiative being spearheaded by a regional watercourse commission. Similar initiatives of inter-basin water transfers should also consider applying the WEF nexus to avoid transferring challenges.

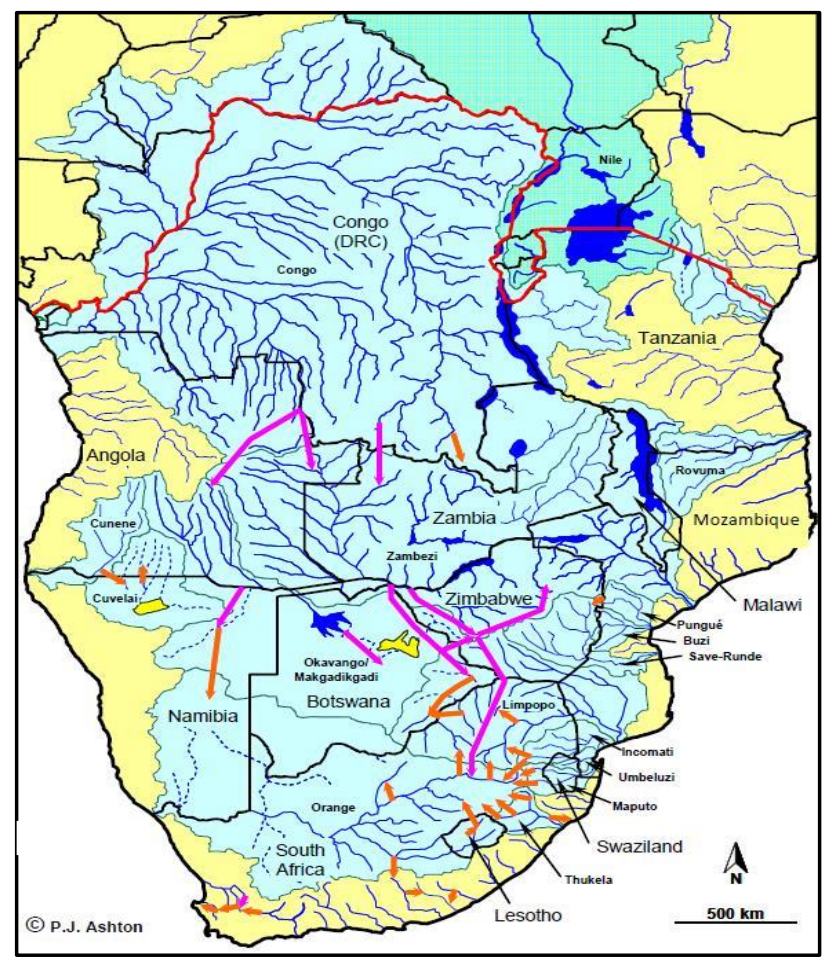

Figure 4. Current and planned inter-basin transfers in southern Africa. Note: Orange lines indicate current transfers; purple lines indicate planned transfers. Source: [9].

In early agriculture, manual labour and oxen provided the means to build irrigation channels to draw water and divert rivers. As of more recently, modern energy is used to pump water from groundwater reserves and divert whole rivers across larger distances. With the global population and global economic growth set to continue and a significant proportion of the current human population lacking access to clean water supply and sewerage services, the energy-for-water challenge has become a significant, global-scale concern, more so in developing regions, and has seen an upsurge of water trading [62]. Underpinning both challenges is the previously described 'water scarcity' issue, and the 
recent challenge of 'water stress' [63]. A WEF nexus approach may be the pedal to deal with these challenges, especially in the advent of climate change.

\subsection{Land and the WEF Nexus}

Across SSA, issues around land are highly contentious, and this is worsened when water issues are introduced. The key land issues of concern in the region include: access to land (individual or collective), rights to land (individual or collective), land tenure (formal or informal), land tenure security (secured or insecure), land governance (transparency and accountability), the use of land (extensive or intensive) and the management of land (protective or productive) [64,65]. In addition, land tenure has bearings on food production, water rights for irrigation, and the expansion of land under bioenergy uses, hence the WEF nexus [10]. The relationship between land and water is politically, economically and culturally complex and this complexity is expected to increase with the progression of growing populations, increasing water and energy scarcity, growing demand for water and energy and food security concerns [7], and more so with the current plans of increasing the land under irrigation.

Land reform fragmentation has also led to infrastructure imbalances [66], and this has delayed the institutionalization of the WEF nexus across the region due to the uncertainty in land and water rights. These factors bring about a complex matrix of land-related factors that impact on the willingness to invest in agriculture and infrastructure, and more so, on the rehabilitation of existing irrigation infrastructure [67]. Statistics are hard to come by in terms of the proportion of farmers in the region with access and a right to securely tenured land [66]; generally, it is agreed that most do not have these $[68,69]$. Consequently, the lack of ownership and or secure land rights also constrains efforts to improve agricultural productivity [66]. Medium-to-long-term investments in irrigation need access to secure land to incentivise such investments. Secured land tenure drives investments in land improvement and agricultural production, the land can be used as collateral, the land can be traded and there is a reduction in conflicts over the access to and use of the land. However, the lack of ownership and or secure land rights, for example, for most women, affect their potential in making effective investments that could contribute to improving agricultural productivity, and by extension, improve household food security.

At a regional level, countries (e.g., Namibia, Mozambique, Tanzania and the Democratic Republic of Congo) in the SADC have international land transfer deals (land grabs) amounting to 10 million ha out of a total of over 50 million ha in the whole of Africa [70]. Land grabs, as they are commonly known, although signed by national governments, have a tendency of negatively impacting the rural farmers' access to productive agricultural land and existing water sources. In worst-case scenarios, land grabs can reduce rural farmers to indentured labourers on these huge farms. All this does not auger well for the productivity of the land, especially in cases where the scale of production is based on small-scale operations by many farmers, as is common in most countries in the region. Another point of interest to note is the land expropriation (alternatively termed land reform or land redistribution) programmes that have happened in countries such as Zimbabwe and Mozambique. The immediate effect of such programmes has been a massive reduction in agricultural productivity and production, to the extent of nations requiring food imports. South Africa is poised for an extensive land expropriation programme in the near future, and it can only be hoped that this will be undertaken in a properly organised manner so as not to affect agricultural output. In this context, indicators modelled around the WEF nexus can be used to develop sound land distribution frameworks that recognize the linkages between agricultural productivity, resource use and land tenure.

\section{Recommendations}

The success of irrigation expansion in the agro-based economies of southern Africa is reliant on a holistic and systematic WEF nexus approach. Whilst food security is a priority, a WEF nexus approach would ensure that trade-offs with energy and water are mitigated whilst maximising the synergies. The following recommendations are suggested: 
- Linking developmental projects related to water, energy and food (agriculture) to the WEF nexus analytical framework to guide decision-making;

- Develop capacity for water storage through dam construction; this should prioritise small dams for small-scale irrigation in rural areas to improve agricultural production and local food security. The focus on dam construction should be balanced with the rehabilitation and maintenance of existing infrastructure as well as investments in ecological infrastructure, which will make more water available sustainably;

- Exploit untapped groundwater resources to counter rainfall variability and add to surface water resources;

- Conjunctive irrigation-green water models for agricultural water management;

- Increased use of alternative water sources, e.g., partially treated wastewater, for peri-urban irrigated agricultural activities to support urban and peri-urban food supplies in quality and quantity;

- Broaden the energy base through pursuing innovative, sustainable and renewable energy sources to increase energy supply and reduce the cost of energy to the consumers. Currently, the cost of energy is often a hindrance to the success of small-scale irrigation schemes;

- Adopt policies that promote small-scale irrigation and empower smallholder famers to adapt and build resilience to climate variability and change;

- Promote innovative, water- and energy-efficient irrigation practices that can enhance economic advantages for irrigated agriculture while mitigating negative environmental impacts. This would include developing remote-sensing and crop-modelling technologies for precision soil water-content determination and irrigation scheduling support; this could reduce overirrigation and energy usage in large-scale irrigation schemes and improve water productivity;

- Prioritise human capacity development and the development of training plans for workers on sustainability as a strategy to support and sustain the innovations and improve the water productivity of new and existing irrigation schemes;

- Align interventions to improve agricultural productivity through irrigation with the Sustainable Development Goals (SDGs); and

- Improved access to and rights to securely tenured land for irrigated agricultural use in rural areas.

While the above WEF nexus policy and technical recommendations add value and future direction, there is a need to also complement these with sound agricultural practices. This would ensure the sustainable implementation of policy and any such interventions. Additional considerations that could be made in this regard include, but are not limited to:

- Improved agronomic practices: currently, the proportion of fertilizer used across SSA is less than $5 \%$ of the global agriculture consumption. Improving soil fertility is critical for efforts aimed at addressing the productivity of the agricultural sector and tackling hunger in the region and increasing return on investments in increasing the area under irrigation;

- Promoting climate-smart agriculture methods that increase food and biofuel crop production and efficient resource use under rainfed and irrigated conditions; and

- Improving the access to and capacity of agricultural advisory services needed to support the technical interventions.

\section{Limitations and Risks}

As already alluded to, the WEF nexus has previously been applied as a conceptual framework for natural resources governance, as a tool for decision support systems (DSS), as a perspective to resources management, as an analytical approach for solution seeking, as a conceptual framework for political analysis and as a web-based tool for management decisions. Despite this wide array of applications, the WEF nexus is not without limitations and risks, especially when applied to a 
subcontinent as diverse as southern Africa. Below are some of the limitations and risks with the WEF nexus, in light of what the authors are proposing in this paper.

(a) Institutional

- Absence of operational WEF nexus policies and their adoption in member countries.

- Lack of buy-in to the WEF nexus from policy people and strategists on the ground.

- Resource limitations from the government departments responsible for coordinating and implementing the WEF nexus.

(b) Technical

- Limitations in the ability of implementing persons to apply and operationalise the WEF nexus.

- Inaccessibility and inadequacies in the data required to effectively apply the WEF nexus.

- Lack of proper tools, e.g., models, to successfully apply the WEF nexus.

- Lack of proper metrics applicable to the region in general and countries specifically.

- Lack of frameworks to measure the success of any WEF nexus implementation and applications.

(c) Sociopolitical

- Shift in political positions by governments that will negate the effective application of the WEF nexus, e.g., change in policies, rules and regulations that govern water, land and energy resources.

- Market manipulations for political expediency, thus negating the proper management of natural and agricultural resources, e.g., drastic land and water reforms.

- Uncontrollable externalities that might dominate the WEF nexus, e.g., climate change/variations or regional political instability.

\section{Conclusions}

It is feasible to increase the area under irrigation in Southern Africa. If done correctly, this could sustainably increase food production and improve food security. Targets to increase the area under irrigation should be matched with available water and energy resources, i.e., adopt a WEF nexus approach. This will allow for coordinated interventions and sustainable improvements in agricultural productivity. The inclusion of smallholder farmers through investments in small-scale irrigation schemes will assist in the development of resilient food systems and strengthening their capacity to adapt to climate variability and change. There is a need for human capacity development to ensure that smallholder farmers are equipped to take advantage of the investments. This will sustain gains achieved from increasing the area under irrigation and may enable farm management to shift towards climate-smart agriculture. In this regard, climate-smart agriculture practices that (i) promote rainwater harvesting and soil water conservation, (ii) the use of improved crop varieties with high water productivity, and (iii) improved agronomic practices and alternative practices such as intercropping that contribute to increased water productivity should be strengthened.

Author Contributions: T.M. conceptualized the study. T.M., S.M., V.G.P.C. and L.N. designed and developed the framework and concept notes. T.M., S.M., V.G.P.C. and L.N. contributed to the writeup, literature review and data analysis. C.N. and A.S. helped with the writeup and literature review. D.N. and A.T.M. contributed to the writeup and quality control.

Funding: The research was funded by the Water Research Commission (WRC) of South Africa through the Research Development Branch. 
Acknowledgments: The authors would like to thank the University of KwaZulu Natal (UKZN), the International Water Management Institute (IWMI) and the Water Research Commission (WRC) for supporting the WEF nexus initiative.

Conflicts of Interest: The authors declare no conflict of interest.

\section{References}

1. Wani, S.P.; Sreedevi, T.K.; Rockström, J.; Ramakrishna, Y.S. Rainfed agriculture-past trends and future prospects. In Rainfed Agriculture Unlocking Potential; CABI: Wallingford, UK, 2009.

2. Cai, X.; Magidi, J.; Nhamo, L.; van Koppen, B. Mapping Irrigated Areas in the Limpopo Province, South Africa; International Water Management Institute (IWMI): Battaramulla, Sri Lanka, 2017; Volume 172, ISBN 9290908513.

3. Shukri Bin Zainal Abidin, M.; Shibusawa, S.; Ohaba, M.; Li, Q.; Marzuki, B.K. Water Uptake Response of Plant in Subsurface Precision Irrigation System. Eng. Agric. Environ. Food 2013, 6, 128-134. [CrossRef]

4. Pretty, J.N.; Morison, J.I.L.; Hine, R.E. Reducing food poverty by increasing agricultural sustainability in developing countries. Agric. Ecosyst. Environ. 2003, 95, 217-234. [CrossRef]

5. New Partnership for Africa's Development (NEPAD). Water in Africa: Management Options to Enhance Survival and Growth; New Partnership for Africa's Development (NEPAD): Addis Ababa, Ethiopia, 2006.

6. New Partnership for Africa's Development (NEPAD). The Malabo Declaration on African Agriculture; New Partnership for Africa's Development (NEPAD): Midrand, South Africa, 2014.

7. Nhamo, L.; Ndlela, B.; Nhemachena, C.; Mabhaudhi, T.; Mpandeli, S.; Matchaya, G. The water-energy-food nexus: Climate risks and opportunities in Southern Africa. Water 2018, 10, 567. [CrossRef]

8. Endo, A.; Kumazawa, T.; Burnett, K.; Ishii, A.; Tsurita, I.; Wada, C.A.; Kato, T.; Yamada, M.; Orencio, P. An Interdisciplinary Approach for Water-Energy-Food Nexus. In The Water-Energy-Food Nexus; Springer: Berlin/Heidelberg, Germany, 2018; pp. 289-299.

9. Rasul, G. Managing the food, water, and energy nexus for achieving the Sustainable Development Goals in South Asia. Environ. Dev. 2016, 18, 14-25. [CrossRef]

10. Biggs, E.M.; Bruce, E.; Boruff, B.; Duncan, J.M.A.; Horsley, J.; Pauli, N.; McNeill, K.; Neef, A.; Van Ogtrop, F.; Curnow, J.; et al. Sustainable development and the water-energy-food nexus: A perspective on livelihoods. Environ. Sci. Policy 2015, 54, 389-397. [CrossRef]

11. Livingston, G.; Schonberger, S.; Sara, D. Sub-Saharan Africa: The state of smallholders in agriculture. In New Directions for Smallholder Agriculture; Via Paolo Di Dono: Rome, Italy, 2011.

12. New Partnership for Africa's Development (NEPAD). Comprehensive Africa Agriculture Development Programme (CAADP); New Partnership for Africa's Development (NEPAD): Midrand, South Africa, 2003.

13. New Partnership for Africa's Development (NEPAD). Implementation Strategy and Roadmap to Achieve the Vision on CAADP: Operationalizing the 2014 Malabo Declaration on Accelerated African Agricultural Growth and Transformation for Shared Prosperity and Improved Livelihood; New Partnership for Africa's Development (NEPAD): Addis Ababa, Ethiopia, 2014.

14. African Union Commission. Malabo Declaration on Accelerated Agricultural Growth and Transformation for Shared Prosperity and Improved Livelihoods; African Union Commission: Addis Ababa, Ethiopia, 2014.

15. Regional Indicative Strategic Development Plan (RISDP). Regional Indicative Strategic Development Plan; RISDP: Gaborone, Botswana, 2015.

16. Southern African Development Community (SADC). Regional Agricultural Policy; SADC: Gaborone, Botswana, 2014.

17. Govender, L.; Pillay, K.; Siwela, M.; Modi, A.; Mabhaudhi, T. Ssfood and nutrition insecurity in selected rural communities of KwaZulu-Natal, South Africa-Linking human nutrition and agriculture. Int. J. Environ. Res. Public Health 2017. [CrossRef]

18. Nhamo, L.; Matchaya, G.; Nhemachena, C.; van Koppen, B. The impact of investment in smallholder irrigation schemes on irrigation expansion and crop productivity in Malawi. Afr. J. Agric. Resour. Econ. 2016, 11, 141-153.

19. Pacetti, T.; Lombardi, L.; Federici, G. Water-Energy Nexus: A case of biogas production from energy crops evaluated by Water Footprint and LCA methods. J. Clean. Prod. 2015, 101, 278-291. [CrossRef] 
20. Mabhaudhi, T.; Mpandeli, S.; Madhlopa, A.; Modi, A.; Backeberg, G.; Nhamo, L. Southern Africa's Water-Energy Nexus: Towards Regional Integration and Development. Water 2016, 8, 235. [CrossRef]

21. IAM (Irrigated area Map) Irrigated area map of Asia (2000-2010) and Africa (2010). Available online: http:/ / waterdata.iwmi.org/applications/irri_area/ (accessed on 5 June 2016).

22. Maleksaeidi, H.; Karami, E. Social-Ecological Resilience and Sustainable Agriculture Under Water Scarcity. Agroecol. Sustain. Food Syst. 2013, 37, 262-290. [CrossRef]

23. International Water Management Institute (IWMI). Irrigated Area Map of Asia (2000-2010) and Africa (2010); IWMI: Colombo, Sri Lanker, 2015.

24. Faurès, J.-M.; Hoogeveen, J.; Bruinsma, J. The FAO Irrigated Area Forecast for 2030; Citeseer: Rome, Italy, 2003.

25. FAO AQUASTAT, Main database. Available online: http://www.fao.org/nr/water/aquastat/main/index. stm (accessed on 5 June 2016).

26. Levidow, L.; Zaccaria, D.; Maia, R.; Vivas, E.; Todorovic, M.; Scardigno, A. Improving water-efficient irrigation: Prospects and difficulties of innovative practices. Agric. Water Manag. 2014, 146, 84-94. [CrossRef]

27. Chimonyo, V.G.P.; Modi, A.T.; Mabhaudhi, T. Simulating yield and water use of a sorghum-cowpea intercrop using APSIM Simulating yield and water use of a sorghum-Cowpea intercrop using. Agric. Water Manag. 2016, 177, 317-328. [CrossRef]

28. Chimonyo, V.; Modi, A.; Mabhaudhi, T. Assessment of sorghum-cowpea intercrop system under waterlimited conditions using a decision support tool. Water $S A$ 2016, 42, 316. [CrossRef]

29. Howell, T.A. Irrigation efficiency. In Encyclopedia Water Science; Marcel Dekker: New York, NY, USA, 2003; pp. 467-472.

30. Siemens, J.A.; Zwiazek, J.J. Effects of water deficit stress and recovery on the root water relations of trembling aspen (Populus tremuloides) seedlings. Plant Sci. 2003, 165, 113-120. [CrossRef]

31. Brandoni, C.; Bošnjaković, B. HOMER analysis of the water and renewable energy nexus for water-stressed urban areas in Sub-Saharan Africa. J. Clean. Prod. 2017, 155, 105-118. [CrossRef]

32. Mpandeli, S.; Backeberg, G.; Mabhaudhi, T.; Modi, A. Water-Energy-Food security nexus: Towards policy convergence. In Proceedings of the South African National Committee on Irrigation and Drainage Symposium, Glenburn Lodge, South African, 18-20 November 2014.

33. Jumbe, C.B.L.; Msiska, F.B.M.; Madjera, M. Biofuels development in Sub-Saharan Africa: Are the policies conducive? Energy Policy 2009, 37, 4980-4986. [CrossRef]

34. Schnoor, J.L. Water-energy nexus. Environ. Sci. Technol. 2011, 45, 5065. [CrossRef]

35. Siddiqi, A.; Anadon, L.D. The water-energy nexus in Middle East and North Africa. Energy Policy 2011, 39, 4529-4540. [CrossRef]

36. Southern Africa Development Community (SADC). Regional Water Infrastructure Programme; SADC: Gaborone, Botswana, 2010.

37. Flora, C.B. Food security in the context of energy and resource depletion: Sustainable agriculture in developing countries. Renew. Agric. Food Syst. 2010, 25, 118-128. [CrossRef]

38. Bogdanski, A. Integrated food-energy systems for climate-smart agriculture. Agric. Food Secur. $2012,1,9$. [CrossRef]

39. Zhou, P.P. Regional Infrastructure Development Master Plan: Energy Sector Plan; SADC: Gaborone, Botswana, 2012.

40. Van der Stoep, I.; Grové, B.; Steyn, M. Reduction in the electricity costs for irrigated potato production in Limpopo. Economic News. August 2016. Available online: http:/ /www.potatoes.co.za/SiteResources / documents/Reduction\%20in\%20the\%20electricity\%20costs.pdf (accessed on 13 November 2018).

41. NSW Farmers Water and Energy: A central productivity issue for Australian farming. Available online: https:/ / www.aginnovators.org.au/initiatives/energy/themes/water-and-energy (accessed on 5 June 2016).

42. Sims, R.; Flammini, A.; Puri, M.; Bracco, S. Opportunities For Agri-Food Chains To Become Energy-Smart; FAO: Washington, DC, USA, 2015.

43. Cervantes-Godoy, D.; Dewbre, J. Economic Importance of Agriculture for Poverty Reduction; OECD Food, Agriculture and Fisheries Papers, No. 23; OECD: Paris, France, 2010.

44. Rulli, M.C.; Bellomi, D.; Cazzoli, A.; De Carolis, G.; D'Odorico, P. The water-land-food nexus of first-generation biofuels. Sci. Rep. 2016, 6, 22521. [CrossRef] [PubMed]

45. Southern African Development Community (SADC). Regional Water Policy; SADC: Gaborone, Botswana, 2005. 
46. Mirzabaev, A.; Guta, D.; Goedecke, J.; Gaur, V.; Börner, J.; Virchow, D.; Denich, M.; von Braun, J. Bioenergy, food security and poverty reduction: Trade-offs and synergies along the water-energy-food security nexus. Water Int. 2015, 40, 772-790. [CrossRef]

47. Kline, K.L.; Msangi, S.; Dale, V.H.; Woods, J.; Souza, G.M.M.; Osseweijer, P.; Clancy, J.S.; Hilbert, J.A.; Johnson, F.X.; McDonnell, P.C.; et al. Reconciling food security and bioenergy: Priorities for action. GCB Bioenergy 2017, 9, 557-576. [CrossRef]

48. Smith, J.U.; Fischer, A.; Hallett, P.D.; Homans, H.Y.; Smith, P.; Abdul-Salam, Y.; Emmerling, H.H.; Phimister, E. Sustainable use of organic resources for bioenergy, food and water provision in rural Sub-Saharan Africa. Renew. Sustain. Energy Rev. 2015, 50, 903-917. [CrossRef]

49. Don, A.; Osborne, B.; Hastings, A.; Skiba, U.; Carter, M.S.; Drewer, J.; Flessa, H.; Freibauer, A.; Hyvönen, N.; Jones, M.B.; et al. Land-use change to bioenergy production in Europe: Implications for the greenhouse gas balance and soil carbon. GCB Bioenergy 2012, 4, 372-391. [CrossRef]

50. Popp, J.; Lakner, Z.; Harangi-Rákos, M.; Fári, M. The effect of bioenergy expansion: Food, energy, and environment. Renew. Sustain. Energy Rev. 2014, 32, 559-578. [CrossRef]

51. Yue, D.; You, F.; Snyder, S. Biomass-to-bioenergy and biofuel supply chain optimization: Overview, key issues and challenges. Comput. Chem. Eng. 2014, 66, 36-56. [CrossRef]

52. Offermann, R.; Seidenberger, T.; Thrän, D.; Kaltschmitt, M.; Zinoviev, S.; Miertus, S. Assessment of global bioenergy potentials. Mitig. Adapt. Strateg. Glob. Chang. 2011, 16, 103-115. [CrossRef]

53. Lynd, L.R.; Sow, M.; Chimphango, A.F.A.; Cortez, L.A.B.; Brito Cruz, C.H.; Elmissiry, M.; Laser, M.; Mayaki, I.A.; Moraes, M.A.F.D.; Nogueira, L.A.H.; et al. Bioenergy and African Transformation. Biotechnol. Biofuels 2015, 8, 18. [CrossRef]

54. Sieber, S.; Tscherning, K.; Graef, F.; Uckert, G.; Paloma, S.G. Food security in the context of climate change and bioenergy production in Tanzania: Methods, tools and applications. Reg. Environ. Chang. 2015, 15, 1163-1168. [CrossRef]

55. Gerbens-Leenes, W.; Hoekstra, A.Y.; van der Meer, T.H. The water footprint of bioenergy. Proc. Natl. Acad. Sci. USA 2009, 106, 10219-10223. [CrossRef] [PubMed]

56. United Nations Conference on Trade and Development (UNCTD). UNCTAD Second Generation Biofuel Markets: State of Play, Trade and Developing Country Perspectives; UNCTD: Geneva, Switzerland, 2016.

57. Tigere, T.A.; Gatsi, T.C.; Mudita, I.I.; Chikuvire, T.J.; Thamangani, S.; Mavunganidze, Z. Potential of Jatropha curcas in improving smallholder farmers' livelihoods in Zimbabwe: An exploratory study of Makosa ward, Mutoko district. J. Sustain. Dev. Afr. 2006, 8, 1-9.

58. International Energy Agency (IEA). Water for Energy: Is Energy Becoming a Thirstier Resource? IEA: Paris, France, 2012.

59. Yamazaki, J.; Yamazak, A. Water and Energy Nexus; A Literature Review; Water in the West: Stanford, CA, USA, 2013.

60. Gadonneix, P.; Kim, Y.D.; Meyers, K.; Ward, G.; Frei, C. World Energy Resources: 2013 Survey; World Energy Council: London, UK, 2013; ISBN 9780946121298.

61. Perret, S.S.R.S. Water policies and smallholding irrigation schemes in South Africa: A history and new institutional challenges. Water Policy 2002. [CrossRef]

62. Montgomery, M.A.; Bartram, J.; Elimelech, M. Increasing Functional Sustainability of Water and Sanitation Supplies in Rural Sub-Saharan Africa. Environ. Eng. Sci. 2009, 26, 1017-1023. [CrossRef]

63. Msangi, J.P. Managing water scarcity in Southern Africa: Policy and strategies. In Combating Water Scarcity in Southern Africa; Springer: Berlin/Heidelberg, Germany, 2014; pp. 21-41. ISBN 9400770960.

64. Boone, C. Legal Empowerment of the Poor through Property Rights Reform: Tensions and Trade-offs of Land Registration and Titling in Sub-Saharan Africa. J. Dev. Stud. 2018, 1-17. [CrossRef]

65. Deininger, K.; Savastano, S.; Xia, F. Smallholders' land access in Sub-Saharan Africa: A new landscape? Food Policy 2017, 67, 78-92. [CrossRef] [PubMed]

66. Hodgson, S. Land and Water-The Rights Interface: Development Law Service FAO Legal Office; Food \& Agriculture Organisation: Rome, Italy, 2004; ISBN 925105214X.

67. Chikozho, C. Understanding Land and Water Sector Reforms in the Context of Smallholder Irrigation and Food Security in the Limpopo River Basin, South Africa: Fieldwork Report; African Institute of South Africa: Pretoria, South Africa, 2016. 
68. Adams, M.; Sibanda, S.; Turner, S. Land Tenure Reform and Rural Livelihoods in Southern Africa; Overseas Development Institute: London, UK, 1999.

69. Drechsel, P.; Dongus, S. Dynamics and sustainability of urban agriculture: Examples from sub-Saharan Africa. Sustain. Sci. 2010, 5, 69-78. [CrossRef]

70. Endo, T.; Kakinuma, K.; Yoshikawa, S.; Kanae, S. Are water markets globally applicable? Environ. Res. Lett. 2018, 13, 034032. [CrossRef] 